\title{
Corporate Social Responsibility and Firm Value: Industry Type and Leverage as Moderating Variables
}

\author{
Erha Isra Nadhara ${ }^{1}$ Jalaluddin*1 Bustamam $^{1} \quad$ Juanda $^{2}$ \\ 1.Accounting Program, Faculty of Economics and Business, Universitas Syiah Kuala, Darussalam, Banda Aceh \\ 23111, Indonesia \\ 2.Management Program, Faculty of Economics and Business, Universitas Syiah Kuala, Darussalam, Banda Aceh \\ 23111, Indonesia
}

\begin{abstract}
The purpose of this research is to examine the influence of corporate social responsibility disclosure toward the firm value using industry type and leverage as a moderating variable. The Kompas 100 Index firms were used in this study, except for financial companies and banks, which are listed on the Indonesia Stock Exchange and submit annual reports or sustainability reports for the years 2017-2019. Multiple regression analysis with a moderate regression analysis method was used to conduct the test. The findings show that: (1) corporate social responsibility disclosure has no impact on firm value, (2) industry type does not moderate the impact of corporate social responsibility disclosure on firm value, and (3) leverage moderates the impact of corporate social responsibility disclosure on firm value.
\end{abstract}

Keywords: Corporate social responsibility disclosure, Firm value, Industry type, Leverage

DOI: $10.7176 / \mathrm{RJFA} / 12-18-05$

Publication date:September $30^{\text {th }} 2021$

\section{Introduction}

The establishment of a firm is of course with clear goals, both short-term goals, and long-term goals. In the short term, maximizing profit is the goal the firm wants to achieve, while in the long term, maximizing firm value is the goal the firm wants to achieve.

Firm value is the shareholder's perception of the firm's success associated with stock prices (Sujoko \& Soebiantoro, 2017). Maximizing the value of the firm can be achieved by establishing a relationship between both parties and synergies between investors, the community, and employees with the firm (Murnita \& Putra, 2018). One of these is through the use of Corporate Social Responsibility (CSR). CSR is an initiative in which the firm is not only responsible for financial matters, but the firm is also responsible for the firm's environmental and social problems with the intention that the firm can grow sustainably (going concern).

In Indonesia, the implementation of CSR is not only voluntary but must be carried out by companies. Article 74 of Law No. 40 of 2007 Concerning Limited Liability Companies regulates this requirement. The existence of regulations governing the obligation to implement CSR does not necessarily make companies comply with these rules. There are still many companies in Indonesia that do not carry out CSR by the laws and regulations. As reported by the Pontianak Tribune (2019), the Governor of West Kalimantan, Mr. Sutarmidji, revealed that the CSR of companies in West Kalimantan was used in an unclear manner. It can be seen from the fact that there are many poor and disadvantaged villages in oil palm plantation locations.

CSR activities carried out by companies in Indonesia are not governed by law, according to N\&P Law Firm Managing Partner Dewi Noviarti. Companies see CSR as a voluntary activity involving the distribution of necessities, rather than a program addressing the needs of the local community, workers, and society in general (Investor.id, 2020).

CSR disclosure does not affect firm value, according to previous research by Nuryana and Bhebhe (2019). As a result, CSR disclosure data has not become a significant factor in investors' investment decisions. The level of CSR disclosure by the firm does not become valuable information for investors. Junardi (2019) finds the reverse, that CSR has a significant impact on a firm's value. The increase in share prices will be caused by the disclosure of the firm's social actions and activities to the general public, indicating that the value of the firm in the eyes of investors will also increase.

The inconsistent results of this study indicate that other variables are indicated to influence firm value. The factor that is thought to be influential is the type of industry. Using samples from three Jordanian industries, the impact of CSR disclosure on corporate value was investigated by Omar and Zallom (2016). CSR has a varying impact on business value in each of the three industries, according to their research. This demonstrates that the kind of industry has an impact on the link between CSR disclosure and firm value.

Another factor that is thought to affect the type of industry is leverage. Leverage reflects how much the firm relies on creditors to finance the firm's assets which will affect the level of investor confidence in investing in shares. Murnita and Putra's research (2018) shows that the higher the level of firm leverage, the lower the implementation of CSR which will affect the decline in firm value. To avoid being singled out by creditors, the 
firm is thought to be decreasing its funding to carry out CSR disclosures and utilizing these monies to pay down the firm's obligations.

\section{Literature Review and Hypotheses Development}

2.1 Signal Theory

Due to information asymmetry, signal theory explains why companies feel compelled to share information with other parties. Investors will be able to use information provided as an announcement as a signal when making investing decisions (Jogiyanto, 2014). When new information is released, market players will first interpret and analyze it to determine whether it is a positive signal (good news) or a negative signal (bad news Investors will be interested in trading shares if the information is deemed to be a good indicator, as evidenced by changes in trading activity (Suwardjono, 2010). Investors respond positively to companies that disclose CSR data. Investors will gain more information if the company makes more disclosures. The larger the risk, the more information investors receive. The more information investors receive, the more confident they become in the company. With a high level of trust, investors will naturally respond positively to the company in the form of rising stock prices (Sahbandi, 2019).

\subsection{Firm Value}

Because the business's market value can bring greatest prosperity to shareholders if the share price improves, Nurlela and Islahuddin (2008) define firm value as market value. The higher the stock price, the greater the firm value. As a result, the company's high firm value is critical (Pohan et al., 2018). Price earning ratio (PER), market-to-book-ratio, Tobin's Q, price/cash flow ratio, and market-to-sales ratio are some of the ratios used to determine a company's market value, according to Sukamulja (2004).

The Tobin's Q ratio is regarded as the most informative ratio because it explains phenomena in the company's operations such as cross-sectional differences in investment decision-making and diversification of the relationship between company value and management's share ownership, the relationship between management performance and profits in acquisitions, and funding policies, compensation, and dividends. All aspects of the company's debt and share capital are included in the Tobin's Q ratio. All firm assets are covered, in addition to common stock and company equity. As a result, this ratio is thought to provide the most useful information (Ramadhani, 2012).

\subsection{Corporate Social Responsibility}

CSR is a business commitment to contribute to sustainable economic growth through collaboration with employees and their representatives, as well as the local community and the wider public, according to The World Business Council for Sustainable Development (1999), the elements of CSR can be summed using this description as firm operations aimed at attaining a balance of economic, environmental, and social issues without jeopardizing shareholder expectations, particularly profit generation (Ramadhani, 2012).

Crowther David (2008) divides the concepts of social responsibility into three categories (Ramadhani, 2012:18), namely:

1. Sustainability, which refers to how the corporation considers future resource sustainability when carrying out activities (actions)

2. Accountability is a public company's effort to hold itself accountable for the operations it has carried out.

3. Transparency, a key principle for external parties, helps to reduce information asymmetry, misunderstandings, and, most importantly, knowledge and accountability for varied environmental repercussions.

\subsection{Corporate Social Responsibility Disclosure}

CSR disclosure, also known as social disclosure, corporate social reporting, and social reporting, according to Mathews (1995), is the process of revealing the social and environmental implications of a company's economic actions on groups interested in the company as a whole. Sustainability Reporting is a report that discloses CSR. Reporting on economic, environmental, and social policies, as well as the influence and performance of businesses and their products in the context of sustainable development, is known as sustainability reporting (Ramadhani, 2012). The disclosure guidelines are based on the Global Reporting Initiatives' guidelines (GRI). The GRI standard was chosen because it focuses more on the disclosure standards of various economic, social, and environmental performance of firms in order to improve the quality, rigor, and usage of sustainability reporting (Setianingrum, 2015).

\subsection{Industry Type}

Different industries are associated with different sorts of businesses. According to Roberts (1992), there are two types of industries. The first is a high-profile industry (environmentally sensitive business), which is one with a 
lot of consumer attention, a lot of politics, and a lot of competitiveness. High-profile industries include oil and gas, as well as basic commodities (steel and chemicals). Low-profile sectors include consumer services and goods, banking, and communications.

Companies working in environmentally sensitive industries that are potentially hazardous to the environment, according to Monteiro and Guzman (2010), must closely adhere to environmental standards since pollution created by industrial activities can harm the ecosystem. Industry that harms the environment, according to Monteiro and Guzman (2010), would experience a lot of social pressure. This is due to the company's direct connection to environmental issues including greenhouse gas emissions and the risk of natural disasters. The corporation will face threats from the community and the government if it does not report its social and environmental duty because it has had a detrimental influence on the environment surrounding it (Pambudi, 2015: 18).

\subsection{Leverage}

Leverage is a metric that determines how much debt is utilized to fund a company's operations (Kasmir, 2016). This ratio assesses a company's ability to meet long-term obligations such as loan interest payments and final debt payments. A long-term debt is one that has a payment due date that is more than a year away. The leverage ratio aids managers and investors in determining the level of risk associated with a company's capital structure (Utami, 2019).

According to Kasmir (2016), there are two techniques to assessing this ratio: measuring balance sheet ratios by looking at the amount to which loans are used for capital and using the profit and loss methodology.

\subsection{The Effect of Corporate Social Responsibility Disclosure on Firm Value}

CSR disclosure is done with the hope that the value of the firm can increase. Because this CSR activity is in favor of the environment and society, people are free to choose good corporate governance and products. When people view the firm well, people will be loyal to the firm's products and will give positive value to the firm. This will have an impact on increasing the good image and stock price of the firm (Pohan et al., 2018).

CSR disclosure has a large and beneficial effect on firm value, according to research by Junardi (2019). This suggests that disclosing corporate social actions will result in a rise in stock prices, which will lead to an increase in the firm's value. The more CSR disclosures made, the more positive signals will be sent to investors, encouraging them to make an investment decision that will boost the firm value. The public, in addition to investors, will give the company a positive signal since it acts within the framework and rules that apply in the place where it is located.

H1: Disclosure of Corporate Social Responsibility affects firm value.

2.8 The Effect of Industry Type in Moderating the Relationship between Corporate Social Responsibility Disclosures and Firm Value

Omar and Zallom (2016) used samples from three different industries in Jordan, namely chemical, food and beverage, and pharmaceuticals, to show that CSR has varying effects on firm value in each industry.

According to Robert (1992), corporations in high-profile industries are thought to reveal more CSR than those in low-profile industries. This is due to the fact that high-profile industries have a high level of political risk, environmental sensitivity, and competition. Furthermore, companies in the high-profile industry category are often companies that receive public attention because their actions have the potential and opportunity of interacting with the general public. (Purwanto, 2011).

H2: Industry type affects moderating the relationship between Corporate Social Responsibility and firm value.

\subsection{The Effect of Leverage in Moderating the Relationship between Corporate Social Responsibility Disclosures} and Firm Value

According to Kasmir (2016), leverage is a ratio that measures how much debt is used to fund the firm's operations. The amount of debt a firm employs to finance itself is also a factor in its long-term viability. If the debt employed is too huge, the firm's future viability is jeopardized, and the chance of corporate bankruptcy rises since the company is locked in a high debt level, making it harder to get out of debt (Murnita \& Putra, 2018).

According to research by Adawiyah (2013), the stronger the firm's leverage, the higher the CSR implementation, which will affect the increase in firm value. The firm's wider disclosure of the information is carried out to dispel creditors' doubts about the non-fulfillment of their rights.

H3: Leverage affects moderating the relationship between Corporate Social Responsibility and firm value.

\section{Research Methods}

3.1 Population and Sample

The Kompas 100 Index Companies on the Indonesia Stock Exchange in 2017-2019 became the research 
population. Based on data sources from the Indonesia Stock Exchange (IDX), in 2017-2019 there were 146 companies listed in the Kompas 100 Index. Purposive sampling was used to select samples to produce a representative sample and meet the criteria. As a result, 32 companies were selected as samples in this study.

The following are some examples of sample criteria to consider.

1. Companies that were consistently featured in the Kompas 100 Index during the 2017-2019 observation period and were listed on the IDX other than financial institutions and banks.

2. Publish a comprehensive annual report every year from 2017 through 2019.

3. Between 2017 and 2019, publish a sustainability report (Sustainability Reporting) or other social data.

4. During the 2017-2019 term, consistently disclose CSR in accordance with GRI G4.

5. Have all of the data you need for the study's variables.

The researcher chose the sample in Table 1 based on the criteria listed above.

Table 1. Research Sample

\begin{tabular}{|l|c|}
\hline \multicolumn{1}{|c|}{ Sample Criteria } & Quantity \\
\hline Companies included in the Kompas 100 Index for the 2017-2019 period & 146 \\
\hline Companies that are not consistently listed in the Kompas 100 Index during the 2017-2019 period & $(76)$ \\
\hline Financial companies and banks & $(11)$ \\
\hline Companies that do not consistently publish complete annual reports during the 2017-2019 period & $(10)$ \\
\hline Companies that do not disclose CSR in accordance with GRI G4 & $(17)$ \\
\hline Final Sample & 32 \\
\hline
\end{tabular}

\subsection{Variable Operationalizations}

\subsubsection{Firm Value}

Tobin's Q is used in this study to measure firm value. If the value of Q is more than one, this indicates that the investment provides a greater return than the investment expenditure, which will encourage future investment. If the $\mathrm{Q}$ value is less than one, then the investment is not attractive (Herawaty, 2008).

3.2.2 Corporate Social Responsibility Disclosure

In this study, CSR disclosure is defined as CSR disclosure in an annual report or a sustainability report. The list of CSR disclosures used in this study uses the list of disclosures contained in Alawiah's research (2017), namely the GRI G4 disclosure index.

The CSR disclosure index is determined by assigning a 1 to things that are revealed and a 0 to those that are not disclosed, then dividing the total number of disclosures by 91 GRI G4 items (Pristianingrum, 2017:359).

\subsubsection{Industry Type}

There are two categories of industrial types: high profile and low profile. High-profile industries consist of chemical, paper, mining, and oil companies, automotive, agribusiness, forestry, food and beverage, health, tobacco and cigarettes, media and communications, tourism, and transportation. While the low profile industry consists of financial and banking companies, building, medical, medical equipment suppliers, textiles and textile products, household goods, retailers, and personal goods. The type of industry is determined by a dummy variable that assigns a score of 1 to high-profile companies and a score of 0 to low-profile companies (Sembiring, 2006).

3.2.4 Leverage

Leverage is estimated in this study by referring to Murnita and Putra (2018), who used a debt-to-equity ratio to compare total debt to total equity.

\subsection{Analysis Method}

In this study, descriptive statistics, classical assumption tests, and Moderated Regression Analysis were utilized to analyze the data (MRA). MRA can be used to determine if a moderating variable increases or weakens the link between independent and dependent variables (Ghozali, 2011:223). The following is the regression model used in this investigation.

Notes:

$\mathrm{Y}=$ Firm value

$\alpha=$ Constant

$\beta 1-\beta 5=$ Regression coefficient

$\mathrm{X} 1=$ Corporate Social Responsibility

$\mathrm{X} 2=$ Industrial type

$\mathrm{X} 3=$ Leverage

$\mathrm{X} 1 . \mathrm{X} 2=$ Interaction between CSR variables and industry type

$\mathrm{X} 1 . \mathrm{X} 3=$ Interaction between $\mathrm{CSR}$ variables and leverage

e $=$ error 


\section{Results and Discussion}

4.1 Descriptive statistics

Table 2. Descriptive statistics

\begin{tabular}{|l|l|r|r|r|r|}
\hline & $\mathrm{N}$ & \multicolumn{1}{|c|}{ Minimum } & Maximum & mean & Std. Deviation \\
\hline CSR & 96 & 0.0220 & 0.1648 & 0.071894 & 0.0408877 \\
Industry Type & 96 & 0 & 1 & 0.6875 & 0.46595 \\
Leverage & 96 & 0.1437 & 4.3430 & 1.223225 & 1.0430702 \\
The value of the firm & 96 & 0.6152 & 7.1078 & 1.869738 & 1.4313069 \\
Valid N (listwise) & 96 & & & \\
\hline
\end{tabular}

The results of the analysis in Table 2 with a total of 96 samples show that during 2017-2019 the average CSR disclosure by companies was 0.0718 or $7.18 \%$. This means that companies disclosing CSR on average are $7.18 \%$ of the 91 disclosure items. The minimum CSR disclosure index is 0.0220 and the maximum is 0.1648 . The findings of the investigation show that few organizations have issued CSR disclosures in accordance with the GRI G4 criteria as a form of social responsibility to stakeholders.

The industrial type variable shows an average value of 0.6875 , a minimum value of 0 , and a maximum value of 1 . An average of 0.6875 indicates that the sample companies are mostly high-profile companies.

The leverage variable's descriptive statistics show an average of 1.2232 when comparing total debt to total equity. This demonstrates that the majority of businesses are capable of paying their obligations. The leverage ratio has a minimum of 0.1437 and a maximum of 4.3430 .

The average value of the firm value variable, as measured by Tobin's Q, is 1.8697 , with a minimum of 0.6152 , a maximum of 7.1078, and a standard deviation of 1.4313 . Tobin's Q 1.8697 indicates that the corporation has made investments in profit-generating assets that are worth more than its investment expenditure.

\subsection{Classic Assumption Test}

\subsubsection{Normality Test}

The normality test is used to determine if the confounding factors or residuals in a regression model are normally distributed or not (Ghozali, 2011: 160). The non-parametric Kolmogorov-Smirnov (K-S) statistical test and normal probability plot graph analysis were employed in this work. Figure 1 depicts the normal probability plot graph.

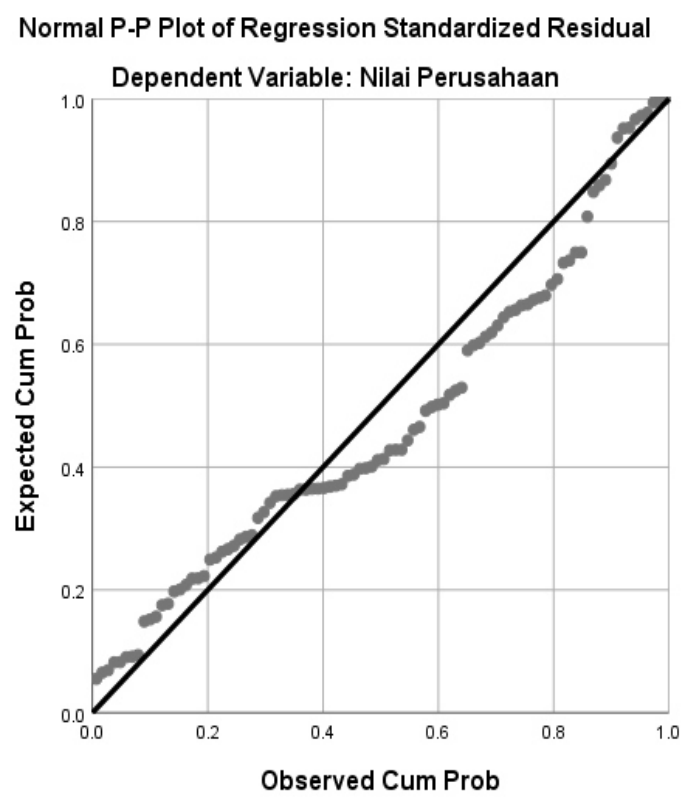

Figure 1. Normal Probability Plot Graph

The data pattern in Figure 1 spreads around the diagonal line and follows the diagonal line's direction, indicating that the data is normally distributed or that the regression model fits the assumption of normality. Table 2 also contains the findings of the non-parametric Kolmogorov-Smirnov (K-S) statistical test. 
Table 3. Kolmogorov-Smirnov Test Result

\begin{tabular}{|ll|l|}
\hline \multicolumn{2}{|l|}{ One-Sample Kolmogorov-Smirnov Test } & \multicolumn{2}{l|}{} \\
\hline & & $\begin{array}{l}\text { Unstandardized } \\
\text { Residual }\end{array}$ \\
\hline $\mathrm{N}$ & & 96 \\
Normal Parameters & & 0.0000000 \\
& Mean & 1.19651946 \\
Most Extreme Differences & Std. Deviation & 0.116 \\
& Absolute & 0.116 \\
Kolmogorov-Smirnov Z & Positive & -0.059 \\
Asymp. Sig. (2-tailed) & Negative & 1.132 \\
a. Test Distribution is Normal & & 0.154 \\
\hline
\end{tabular}

The number 0.154 appears as an asymp. Sig. (2-tailed) on the results of the Kolmogorov-Smirnov test in Table 3. This number is higher than the significance level of 0.05 . The data is normally distributed or consistent with the normal probability plot graph test based on these results, thus the regression model can be utilized for the following test.

\subsubsection{Multicollinearity Test}

The multicollinearity test is used to determine whether or not there is a correlation between independent variables in a regression model (Ghozali 2011:105). The value of tolerance and the variance inflation factor show multicollinearity (VIF). When the tolerance value is 0.10 and the VIF value is 10 , multicollinearity arises. Table 3 shows the results of the multicollinearity test.

Table 4. Multicollinearity Test Result

\begin{tabular}{|ll|r|r|}
\hline \multirow{2}{*}{ Model } & \multicolumn{2}{|c|}{ Collinearity Statistic } \\
\cline { 3 - 4 } & & Tolerance & \multicolumn{1}{|c|}{ VIF } \\
\hline & Constant) & 0.066 & 15.168 \\
& CSR & 0.173 & 5.784 \\
& Tipe Industri & 0.131 & 7.605 \\
& Leverage & 0.036 & 27.518 \\
& CSR.Tipe Industri & 0.089 & 11.231 \\
& CSR.Leverage & &
\end{tabular}

Table 4 shows that the variables CSR, CSR.Industrial Type, and CSR.Leverage have tolerance values of less than 0.10 and a VIF value of more than 10. This indicates that these variables are multicollinear. Multicollinearity is a common occurrence in research that include moderating variables.

4.2.3 Heteroscedasticity Test

The heteroscedasticity test was used to see if there was a difference in variance between the residuals of one observation and the residuals of another observation in the regression model. Heteroscedasticity does not occur in a good regression model. The heteroscedasticity test was performed in this study by plotting the predicted value of the dependent variable (ZPRED) against the residual value (SRESID). Figure 2 shows the results of the heteroscedasticity test. 
Figure 2. Scatterplot Graph

Scatterplot

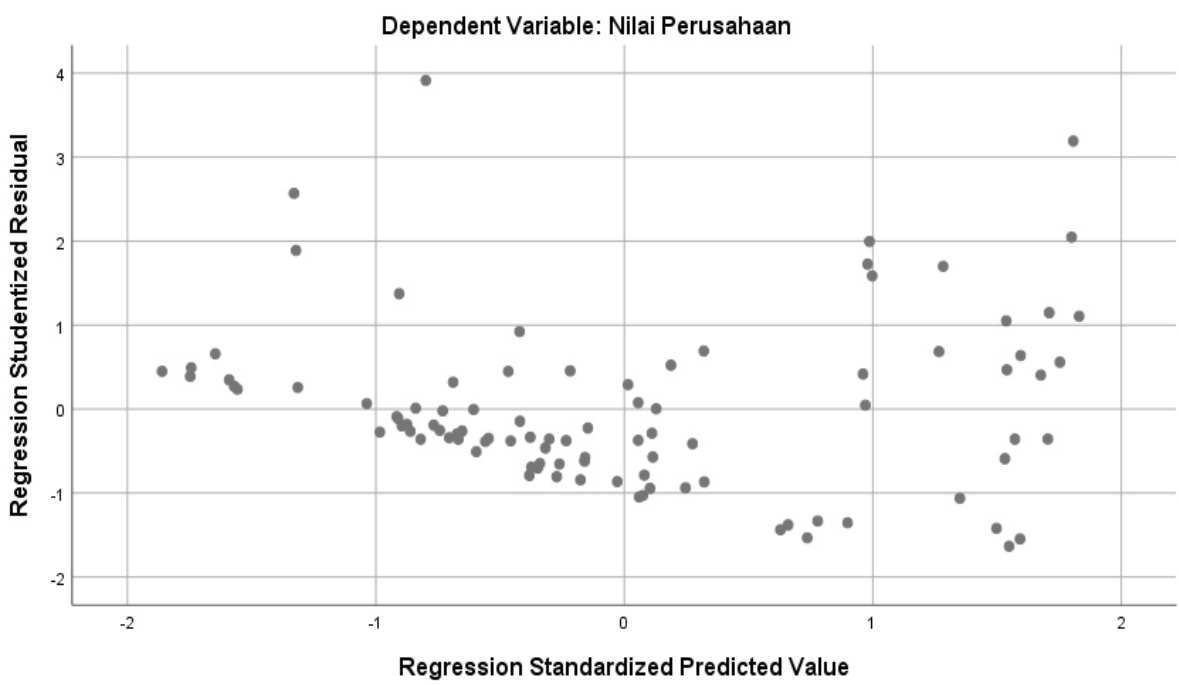

Figure 2 shows that there is no discernible pattern and that the dots are randomly distributed above and below the number 0 on the $\mathrm{Y}$ axis. This indicates that there is no heteroscedasticity in the regression model, allowing it to be used for further testing.

4.2.4 Autocorrelation Test

The autocorrelation test is used to see if there is a correlation between residuals in period $t$ and residuals in period t-1 (prior) in a linear regression model (Ghozali, 2011:110). A decent regression model is one that does not have any autocorrelation. The Durbin-Watson test (DW test) is used in this investigation to see if there is a correlation. Table 4 shows the results of the autocorrelation test.

Table 5. Autocorrelation Test Result

\begin{tabular}{|c|r|r|r|r|r|}
\hline Model & $\mathrm{R}$ & $\mathrm{R}$ Square & $\begin{array}{c}\text { Adjusted R } \\
\text { Square }\end{array}$ & $\begin{array}{c}\text { Std. Error of the } \\
\text { Estimate }\end{array}$ & Durbin-Watson \\
\hline 1 & $0.549^{\mathrm{a}}$ & 0.301 & 0.262 & 1.2293069 & 0.819 \\
\hline
\end{tabular}

a. Predictors: (Constant), CSR*Leverage, CSR*Tipe Industri, CSR, Tipe Industri, Leverage

Table 5 shows the results of the autocorrelation test, which yielded a Durbin-Watson value of 0.819 . Because the Durbin-Watson value remains in the -2 to +2 range, the regression model can be concluded to be autocorrelation-free.

4.3 Moderate Regression Analysis

Table 6. Moderate Regression Analysis Test Results

\begin{tabular}{|c|c|c|c|c|c|c|}
\hline \multicolumn{7}{|c|}{ Coefficientsa } \\
\hline & & \multicolumn{2}{|c|}{$\begin{array}{l}\text { Unstandardized } \\
\text { Coefficients }\end{array}$} & $\begin{array}{l}\text { Standardized } \\
\text { Coefficients }\end{array}$ & & \\
\hline Model & & $\mathrm{B}$ & Std. Error & Beta & $\mathrm{T}$ & Sig. \\
\hline \multirow[t]{4}{*}{1} & (Constant) & 3.367 & 0.571 & & 5.893 & 0.000 \\
\hline & CSR & -19.808 & 12,014 & -0.566 & $-1,649$ & 0.103 \\
\hline & CSR.T.Industry & 0.842 & 12.706 & 0.031 & 0.066 & 0.947 \\
\hline & CSR.Leverage & 8052 & 3.325 & 0.715 & 2.421 & 0.017 \\
\hline
\end{tabular}

In Table 6 the CSR disclosure variable shows a significance value of 0.103 . A significance value of more than 0.05 means that $\mathrm{H} 1$ is rejected. This means that CSR disclosure has no bearing on the firm value. Every time a CSR disclosure is made, the firm value drops by 19,808. This study's findings are in line with those of Pohan et al. (2018), Nuryana and Bhebhe (2019), Purawan and Wirakusuma (2020), and Sopian and Mulya (2020). (2018).

CSR disclosure information has not become an essential concern for investors, according to Nuryana and Bhebhe (2019). Regardless of how much attention the corporation pays to its social and environmental duties, investors tend to sell and buy shares. Financial variables and news are preferred by investors when selling and buying stocks on a daily basis. While the impact of CSR is intangible in the near term, it is significant in the long run as a means of ensuring the company's long-term viability.

CSR disclosure that does not follow the Global Reporting Initiative's rules is also a factor in the 
ineffectiveness of CSR disclosure on company value. Companies frequently disclose CSR without providing specific measurement data or information on the impact of their CSR actions. As a result, investors are paying less attention to the company's disclosures because the information provided cannot be used by investors to make investment decisions.

The regression coefficient value for the interaction between CSR disclosure and industry type is 0.066 , with a significance value of $0.947 . \mathrm{H} 2$ is rejected because the significance value is greater than 0.05 . As a result, the kind of industry has no bearing on the impact of CSR disclosure on firm value. The contribution of CSR to business value is unaffected by industry. The findings of this study agree with those of Astuti et al. (2018), who found that industry type has no effect on the association between CSR disclosure and business value.

The implementation of CSR, which is a legal requirement for all businesses in Indonesia, encourages businesses to disclose CSR in order to expand sustainably. Even though it is in a high-profile business, the firm does not have to reveal as much CSR as a form of social duty, and vice versa, even if it is in a low-profile industry, the company attempts to disclose as much CSR as possible as a form of social responsibility.

The moderating variable's regression coefficient value, specifically the interaction between CSR and leverage, is 8.502 with a significance value of 0.017 . $\mathrm{H} 3$ is allowed because the significance value is less than 0.05. This suggests that leverage can mitigate the impact of CSR disclosure on a firm value. The findings of this study are consistent with Cahya's (2010) dan Adawiyah's research. High-leverage companies will be encouraged to produce more extensive CSR reports. According to agency theory, corporations with a high level of leverage will reveal more information in order to alleviate bondholders' concerns about the fulfillment of creditor rights. The interplay of CSR disclosure variables with leverage will boost the firm's value by 8.502 .

The findings of this study contradict those of Murnita and Putra (2018), who found that the higher a company's leverage level, the lower its CSR implementation and, as a result, the worse the company's worth.

\section{Conclusions, Limitations and Suggestions}

From the previous discussion, it can be concluded that:

1. CSR disclosure does not affect firm value. This is because the CSR disclosed has not become important information for investors' consideration in investing. Investors prefer financial factors as a consideration in selling and buying shares. In addition, CSR disclosures that are not by the guidelines issued by GRI cause investors to be unable to consider this information in making investment decisions.

2. The association between CSR disclosure and business value is unaffected by industry type. Mandatory CSR makes companies with two different industries seek to disclose CSR so that companies grow sustainably.

3. The association between CSR disclosure and corporate value is moderated by leverage. The more the firm's leverage, the more CSR disclosure is required. Wider disclosures are made to reduce creditors' doubts about the non-fulfillment of their rights.

The limitation of this research is that this research uses only Kompas 100 Index companies as samples. Then, the independent variable of this research is only CSR, and the information obtained in the study is only limited to the annual report.

Suggestions for future research are to consider using a wider research object. In addition, researchers can also consider adding other independent variables in the study, as well as moderating variables. Furthermore, companies can look for other sources of information regarding CSR disclosures to obtain information on CSR disclosures made by the firm.

\section{References}

Adawiyah, Ira Robiah. (2013). Pengaruh Tipe Industri, Ukuran Perusahaan, Profitabilitas dan Leverage pada Pengungkapan Corporate Social Responsibility (Studi Empiris pada Perusahaan Go Public yang Terdaftar di Jakarta Islamic Index Periode 2008-2012). Thesis. Universitas Islam Negeri Syarif Hidayatullah, Jakarta.

Alawiah, Siti Zahra. (2017). Pengaruh Pengungkapan CSR dan Informasi Keuangan terhadap Abnormal Return (Studi Empiris pada Perusahaan Pertambangan dan Perusahaan Pertanian yang Terdaftar di Bursa Efek Indonesia pada Periode 2011-2015. Thesis. Universitas Islam Negeri Syarif Hidayatullah, Jakarta.

Astuti, H.H., Oktavianus, R.A., \& Agustine, Y. (2018). Pengaruh Pengungkapan Corporate Social Responsibility dan Kinerja terhadap Nilai Perusahaan dengan Tipe Industri sebagai Variabel Moderasi. Jurnal Magister Akuntansi Trisakti, 5 (2), pp. 185-202.

Ghozali, Imam. (2011). Aplikasi Analisis Multivariate dengan Program IBM SPSS 19. 5th ed. Semarang: Universitas Diponegoro.

Herawaty, Vinola. (2008). Peran Praktek Corporate Governance sebagai Moderating Variabel dari Pengaruh Earning Management terhadap Nilai Perusahaan. Jurnal Akuntansi dan Keuangan, 10 (2) , pp. 97-108.

Investor.Id. (2020). Salah Kaprah CSR di Indonesia. https://investor.id/business/salah-kaprah-csr-di-indonesia. [Accessed 30 January 2021]

Jogiyanto, H. (2014). Teori Portofolio dan Analisis Investasi. 9th ed. Yogyakarta: BPFE. 
Junardi, J. (2019). Pengaruh Pengungkapan Corporate Social Responsibility terhadap Nilai Perusahaan dengan Ukuran Perusahaan sebagai Variabel Moderasi. Jurnal Pendidikan Ekonomi, 4 (2), pp. 69-79.

Kasmir, K. (2016). Analisis Laporan Keuangan. Jakarta: PT Rajagrafindo Persada.

Murnita, P.E.M., \& Putra, I.M.P.D. (2018). Pengaruh Corporate Social Responsibility terhadap Nilai Perusahaan dengan Profitabilitas dan Leverage sebagai Variabel Moderasi. E-Jurnal Akuntansi Universitas Udayana, 23 (2), pp. 1470-1494.

Nuryana, Ida., \& Bhebhe, Elisabet. (2019). Pengungkapan Corporate Social Responsibility terhadap Nilai Perusahaan dengan Profitabilitas sebagai Variabel Moderating. Accounting and Financial Review, 2 (2), pp. 142-146.

Omar, Bilal Fayiz., \& Nidal Omar Zallom. (2016). Corporate Social Responsibility and Market Value: Evidence from Jordan. Journal of Financial Reporting and Accounting, Vol. 14.

Pambudi, Waskito Bagus.(2015). Analisi Pengaruh Ukuran Perusahaan, Leverage, Profitabilitas, dan Tipe Industri terhadap Enviromental Disclosure (Studi Empiris pada Perusahaan yang Terdaftar di PROPER dan BEI Tahun 2011-2013). Thesis. Universitas Diponegoro, Semarang.

Pohan, H.T., Noor, I.N., \& Bhakti, Y.F. (2018). Pengaruh Profitabilitas dan Pengungkapan Corporate Social Responsibility terhadap Nilai Perusahaan dengan Ukuran Perusahaan sebagai Variabel Moderasi. Jurnal Akuntansi Trisakti, 5 (1), pp. 41-52.

Popa, Raluca Andreea. (2015). The Corporate Social Responsibility Practices in The Context of Sustainable Development: The Case of Romania. Procedia Economics and Finance, Vol. 23, pp. 1279-1285.

Pristianingrum, N. (2017). Pengaruh Ukuran, Profitabilitas, dan Pengungkapan CSR terhadap Nilai Perusahaan Manufaktur yang Terdaftar Di Bursa Efek Indonesia. Prosiding Seminar Nasional Dan Call For Paper Ekonomi Dan Bisnis, pp. 353-364.

Purwanto, Agus. (2011). Pengaruh Tipe Industri, Ukuran Perusahaan, Profitabilitas terhadap Corporate Social Responsibility. Jurnal Akuntansi \& Auditing,. 8 (1), pp. 1-94.

Ramadhani, Laras Surya. (2012). Pengaruh Corporate Social Responsibility terhadap Nilai Perusahaan dengan Prosentase Kepemilikan Manajemen sebagai Variabel Moderating pada Perusahaan Manufaktur yang Terdaftar di BEI. Thesis. Universitas Diponegoro, Semarang.

Roberts, Robin W. (1992). Determinants Of Corporate Social Responsibility Disclosure: An Application Of Stakeholder Theory. Accounting, Organisations and Society, Vol. 17, No. 6, pp. 595-612.

Sahbandi, Jusman. (2019). Pengaruh Corporate Social Responsibility (CSR) Terhadap Kinerja Keuangan Perusahaan (Studi Empiris pada Perusahaan Perbankan yang Terdaftar di Bursa Efek Indonesia (BEI) Tahun 2015-2016). Thesis. Universitas Mercu Buana, Yogyakarta.

Sembiring, Eddy Rismanda. (2006). Karakteristik Perusahaan dan Pengungkapan Tanggung Jawab Sosial: Study Empiris Pada Perusahaan yang Tercatat di Bursa Efek Jakarta. Jurnal Maksi, 6 (1), pp. 69-85.

Setianingrum, Wahyuning Ambar. (2015). Pengaruh Corporate Social Responsibility terhadap Nilai Perusahaan dengan Profitabilitas sebagai Variabel Moderasi (Studi pada Perusahaan Manufaktur yang Terdaftar di Bursa Efek Indonesia Periode 2011-2013). Thesis. Universitas Negeri Semarang.

Sujoko, \& Soebiantoro, U. (2017). Pengaruh Struktur Kepemilikan Saham, Leverage, Faktor Intern dan Faktor Ekstern Terhadap Nilai Perusahaan. EKUITAS (Jurnal Ekonomi Dan Keuangan), 11 (2), pp. 236.

Suwardjono, S. (2010). Teori Akuntansi: Perekayasaan Laporan Keuangan. 3rd ed. Yogyakarta: BPFE.

TribunPontianak. (2019). Kontribusi CSR, Fakta atau Fiktif?. https://pontianak.tribunnews.com/amp/2019/10/18/kontribusi-csr-fakta-atau-fiktif?page=2. [Accessed 30 January 2021] 